OPEN ACCESS

UNIVERSITY OF THE

WEST of SCOTLAND

UWS Academic Portal

\title{
Glasgow's evolving urban landscape and gang formation
}

McLean, Robert

Published in:

Deviant Behavior

DOI:

$10.1080 / 01639625.2018 .1431042$

Published: 01/01/2019

Document Version

Peer reviewed version

Link to publication on the UWS Academic Portal

Citation for published version (APA):

McLean, R. (2019). Glasgow's evolving urban landscape and gang formation. Deviant Behavior, 40(5), 498-509. [1431042]. https://doi.org/10.1080/01639625.2018.1431042

\section{General rights}

Copyright and moral rights for the publications made accessible in the UWS Academic Portal are retained by the authors and/or other copyright owners and it is a condition of accessing publications that users recognise and abide by the legal requirements associated with these rights.

Take down policy

If you believe that this document breaches copyright please contact pure@uws.ac.uk providing details, and we will remove access to the work immediately and investigate your claim. 
"This is an Accepted Manuscript of an article published by Taylor \& Francis Group in Deviant Behavior on 30/01/2018, available online: http://

www.tandfonline.com/10.1080/01639625.2018.1431042." 


\title{
Glasgow’s Evolving Urban Landscape and Gang Formation
}

Robert Mclean, Interdisciplinary Research Unit on Crime, Policing and Social Justice, School of Education, University of the West of Scotland, Ayr Campus, KA8 0SX, UK.

Telephone:01292886000; email: robert.mclean@uws.ac.uk

\begin{abstract}
Glasgow has long been synonymous with gangs, yet literature remains limited. This article seeks to contribute twofold by first analysing how the evolving urban landscape of Glasgow during, and immediately after industrialisation, contributed to gang formation and reformation in the form of razor gangs, and then what Mclean (2017) terms the Young Street Gang (YSG). Secondly, by examining both gang types the author is able to demonstrate how in the corresponding wider urban context, gangs respond in kind, and questions whether or not, situated within a new era of urbanization, we are witnessing the emerging new face of Glasgow gangs.
\end{abstract}

KEYWORDS: Gangs, Glasgow, Urbanization. 


\section{INTRODUCTION}

Glasgow has long been synonymous with the gang. Gang culture has in many ways become an embedded feature of Glasgow’s social fabric. During the early $20^{\text {th }}$ century Glasgow was coined the Scottish Chicago in relation to heightened gang violence; often the result of sectarian tension following large scale Catholic Irish migration into the industrializing city (Davies 1998; 2013). The infamous razor gang ${ }^{1}$ has come to epitomise this period of gang violence. Interrupted by the Second World War, the interwar years saw the demise of razor gangs (Davies 2013). However, only decades later would the problematic issues of gangs and gang violence once again come to the forefront of Glasgow's social issues. Throughout the 1980s until the 2000s, Glasgow housing estates would be characterized by what the author terms Young Street Gangs (YSG) ${ }^{2}$. The gang is always relevant to context, and in contemporary Glasgow, the YSG gang typology is the one which is most recognisable within literature and media sources. Mclean $(2017)^{3}$ presents an evolving gang model to more accurately capture gang progression, or development, from recreational peer groups to organised criminal groups (See Figure 1 below).

Figure 1: Mclean's evolving Scottish gang model

In addition, McLean also argues that an overly fixative gaze upon the YSG has proved detrimental, not only to the study, but even to the identification, of other gang typologies.

\footnotetext{
${ }^{1}$ The open barbers' razor was a blade which could be folded away and was regularly used by gangs of this period as a method for assaulting rivals. Typically, such attacks were aimed at an opponent's face and cheek. This practice continues today and in Glasgow is referred to as 'slashing' or being 'slashed'.

${ }^{2}$ YSG is an umbrella term used to accurately capture the 'gang' type which is referred to most commonly throughout academic literature in regards to the contemporary study of Glasgow gangs. YSG differ significantly in a variety of ways from the razor gangs. For a more detailed discussion see McLean (Forthcoming).

${ }^{3}$ See McLean (Forthcoming) for more detailed analysis of gang evolution in Scotland.
} 
Adhering to intergenerational gang narratives amongst local populations, the YSG again adopted knife practice as an inherent feature of gang behaviour. This period of YSG activity accumulated in the city being found to have more street gangs than London, and also branded Europe’s knife capital (BBC 2013; Deuchar 2009; VRU 2011). Both the razor gang and the YSG were, and are, very much products of the socio-economic climate they find themselves in.

Recent years though have seen a steady decline in YSG activity. Concentrated efforts by the Scottish Government, Police Scotland, and community based initiatives have arguably combined to aid the decline in both knife use and YSG activity (Deuchar 2013). However, a more critical approach would point out that violence among youths is dropping across not only Britain, but also many westernized countries as a whole. Therefore, it is arguable that wider socio-economic, cultural, and political processes are acting as the primary driving force behind reductions in street gang activity. Although, upon closer inspection we also see that this reduction of YSG activity has coincided with the steady rise of organised crime (OC). This is particularly evident in and around the Glasgow conurbation. Currently the region retains $70 \%$ of Scotland's organised criminal activity; $65 \%$ of which is directly related to drug-dealing gangs. The Scottish Government, 2015 report Scotland Serious Organised Crime Strategy, terms these gangs as Serious Organised Crime Groups (SOCGs). SOCG criteria is defined as: “a) involve[ing] more than one person; b) [are] organised, meaning that it involves control, planning, and use of specialist resources; c) [can] cause, or has the potential to cause, significant harm; and d) benefits [those] individuals concerned, particularly [with] financial gains” (Scottish Government 2015a:6). While the razor gang was a product of rapid industrialisation, the YSG was the result of deindustrialization, along with failed housing polices and advanced youth marginalization. Therefore, given that the 
current socio-economic climate has continued to evolve towards a period of advanced capitalism - characterized by technology, polarization of wealth, individualism, 'disembedded' communities, consumer identity, and welfare retrenchment - the author questions whether or not the decline in YSG activity should be scrutinized more carefully (Beck 1992; Giddens 1992). Rather than assuming YSGs are on their way out, we need to assess whether or not they are simply undergoing an evolutionary change, more suited to the socio-economic climate and urban landscape they find themselves within.

The author will seek to assess whether or not we are seeing the new emerging face of Glasgow gangs, in an era of increased transitional and OC crime (Scottish Government 2015a). Yet given that YSGs have only been in decline in the past few years, it would be difficult to assess the current climate alone, as this would prove futile, rather the author attempts to address this issue by drawing upon past experiences and learning from them. While acknowledgment is given, however limited this may be, that razor gangs and YSGs are quite different in how either presents itself, little effort has been paid to comparing and contrasting exactly how the changing urban landscape contributed to differing gang formations, and subsequent gang activity. Thus only by analysing both, gangs within their time periods, and comparing and contrasting how gang formation and activity coincided with the urban landscape of that period, can we begin to analyse the contemporary climate and question if Glasgow gangs are once again undergoing transformation in efforts to meet the climate they are located within. The article will do this by first analyzing the razor gang, located within Glasgow industrialization, before subsequently analyzing the YSG, this time located within the cities deindustrialization. A discussion will then ensue where the author will compare and contrast the razor gang and YSG, and point out how the urban landscape contributed to differences between the gangs. Doing so will enable the author to discuss 
whether or not in the contemporary era, Glasgow gangs are once again undergoing change. The author does so by drawing upon Mclean’s (2017) model of gang progression, and extends it by suggesting that gangs may be more likely to evolve along certain trajectories dependent upon the broader urban landscape and economic environment they find themselves situated in.

\section{GLASGOWS INDUSTRIALIZATION, DEINDUSTRIALIZATION, AND GANG FORMATION}

\section{Industrialisation and the razor gang}

Glasgow's razor gangs were very much a product of their era, thus they cannot be accurately accounted for without first acknowledging the urban landscape they found themselves situated in. By the end of the $19^{\text {th }}$ century Glasgow was coined the Second City of the British Empire and was producing over half of Britain's tonnage of shipping and a quarter of all locomotives in the world (Fraser 2011). This period of growth was a product of the city's industrialization, which consequently corresponded with a rapid population influx; primarily comprising of Catholic Irish immigrants. While emigration to Scotland had been a regular feature of Irish life during the early-mid $19^{\text {th }}$ century, most emigration was temporary and revolved around the farming calendar. However, as a consequence of the great famine in 1846, a significant proportion of Catholic Irish capitalized on existing migrant networks to Scotland, and made a permanent move to the country (Kenefick 2000). According to the 1841 population census, the Irish-born population of Scotland stood at 126,321 out of a total 
population of 2,620,184. A decade on, this would change significantly as the Irish-born population rose to 207,367 , out of a total of 2,888,742. Thus between 1841 and 1851 the Irish population of Scotland increased 90\%. However, it was the industrial areas of the West of Scotland which saw the largest concentrations of Irish immigrants, with almost $29 \%$ of all Irish migrants settled in Glasgow. During 1848, the average weekly inflow of Irish into Glasgow was estimated at over 1000, and the figure for January to April of that year was put at 42,860 (Handley 1947).

The influx of Catholic Irish into Glasgow had a profound effect on the city's social life. Catholic Irish populations tended to settle in homogeneous communities which often ran directly adjacent to those communities of the indigenous Protestant Scottish population (Handley 1947). Close proximity, increased competition in the labour market, impoverishment, and conflicting religious ideology all contributed to heightening tensions between these communities. This tension often manifested itself in sectarian conflict (Davies 2013). In addition, the Church of Scotland and other Protestant institutions at the time actively encouraged anti-Catholic feelings; sectarianism was firmly entrenched in many of Scotland's most basic institutions of this era. Even as late as 1923, the Church of Scotland published a pamphlet entitled The Menace of the Irish Race to our Scottish Nationality (Handley 1947). This tension would only be heightened further following an economic Depression during this period, which resulted in wide scale unemployment. Many of the skilled indigenous Protestant work force blamed the Catholic Irish, who were already seen to be second class citizens and a source of cheap labour. Out of this melting pot, the razor gangs were born. Gangs like the Penny Mobs, had already been present in the city prior to these processes, but the razor gang was a product of its time and differed in many aspects, namely that they were sectarian fighting outfits who adhered to knife carrying practices (McLean 
Forthcoming). While there were many gangs in the city; however, two of the most infamous were the Protestant Bridgeton Boys and the Roman Catholic Norman Conks. Given geographical proximity, both gangs would clash regularly. The Bridgeton Boys were founded by Billy Fullerton, who demanded the gang adopted a militaristic style of behaviour, such as marching parades, forming their own bands, composing anti-Catholic songs, and a militaristic dressed style (See Figure 2). Given that members tended to be late adolescents and young adults, a junior section called the Derry boys, was also created. Several gangs replicated this model throughout the city and had junior sections (Boyle 1977). These sections would lay the foundations for YSG formation in subsequent decades.

Figure 2: Billy Boys Gang

While razor gangs retained territorial properties, nonetheless such territoriality was largely centred upon religious division. Territory was used as a mechanism for identifying population heritage and religion. Catholic Irish and Protestant Scottish communities lived side by side but were very much segregated from one another, and remained independent and unassimilated. Thus the gangs' territorial identity was largely bound up in sectarian hatred. For such reasons, razor gangs typically engaged in territorial violence (McLean 2017). Yet Boyle (1977) identifies a small close-knit group of offenders as being the gang core, to which the fighting entourage would typically attach themselves and affiliate with in times of battle. Association was largely dependent upon circumstances as members' drift in and out of gang affiliation (Matza 1964). Yet the core body of the gang tended to comprise of what Farrington, Coid, and Murray (2009) would coin persistent offenders; that is individuals displaying intrinsic criminality who typically engage in crime at an early onset and often 
display lengthy criminal careers. The core body would engage in territorial violence but would also engage in OC or crime which was organised. Bartie (2010) and Davies (1998, 2007), both draw attention to the fact that Glasgow razor gangs regularly participated in crime-for-profit activities including racketeering, extortion, and jewellery heists. This is supported by police autobiographical accounts (Sillitoe 1956). Davies $(1998,2007)$ attributes such behaviour to the fact that razor gang members tended to be older and likewise, during the economic depression, used the gang as a means for sustaining income.

In the preceding decades leading up the Second World War, the razor gangs would gradually diminish. While Percy Sillitoe’s aggressive and heavy handed police tactics are often credited with much of the demise of the razor gangs, it is arguable whether this is a plausible explanation given that the War of 1939 was looming, social reform was occurring, and likewise gang scholars also suggest that heavy handed police tactics or intervention strategies often only served to further embed gang mentality and increased gang solidarity (Alonso 2004; Klein 1975). Figure 3 (below), exemplifies the lack of respect for police officers by razor gang members; in which a razor gang member makes an effort to slash a plain clothed police officer attempting to make an arrest. Either way, the razor gang was a consequence of Glasgow’s changing urban landscape. 


\section{Deindustrialization and YSGs}

If the razor gangs where tied to Glasgow's industrialization, then YSGs must be bound up in the cities deindustrialization. Following the Second World War, Britain entered a period of rebuilding and social engineering. A universal health care system was established, the foundations for the welfare state we know today were underway, and heavy industry was again to prove the backbone of the economy (Johnston and McIvor 2004). In regards to housing, the city of Glasgow undertook massive reconstruction projects aimed at creating a large expanse of social housing, for what was predominantly a working-class population. Glasgow housing had previously been characterised by slum Victorian tenements, overcrowding, and poor sanitation. As part of the expanse on social housing, Glasgow Housing Association (GHA) would develop four large peripheral housing estates on the boarders of the city, in addition to the development of numerous tower blocks ${ }^{4}$ and several new towns out with the city boundaries, like Cumbernauld (Smith 1975). Such efforts were undertaken to reduce the cities swelling population (Smith 1975). Much of the population from Glasgow's slum housing would be relocated to these areas in the preceding years. While on the one hand this deconstructed religious homogeneous communities, on the other hand other social problems would soon emerge with the peripheral housing estates of Castlemilk, Drumchapel, Easterhouse, and greater Pollok ${ }^{5}$ in particular (See Figure 4 below). Intended to be semi-self-functioning town-like estates, these areas were characterised by poorly built four story post-war tenements, had little recreational facilities, and lacked either local employment opportunities or adequate transport to inner city, or industrial, areas. The population of these estates had already been typically poor, yet now they would become both marginalised and

\footnotetext{
${ }^{4}$ Glasgow embraced the tower block in an effort to address the problem of slum housing and overcrowding. This resulted in Glasgow having more tower blocks (defined here as 6 stories high or more) than any other UK city.

${ }^{5}$ These four peripheral housing estates are typically referred to as 'Glasgow's big four'. The populations for these estates alone typically ranged from 30,000 residents and above.
} 
isolated. Deindustrialization of the cities heavy industry in proceeding years would only accelerate such processes (Deuchar 2009).

Figure 4: Glasgow's 'big four' peripheral housing estates following their initial construction.

The last few decades of the $20^{\text {th }}$ century would see the decline of heavy industry in Glasgow (Johnston and McIvor 2004). Technological advancements and complex processes apropos globalization would result in the rise of the free market. For westernized countries like the UK, this coincided with a move towards becoming a service sector society, as heavy industry relocated to other industrializing countries (Wacquant 2008). With much of Glasgow’s population based within working-class communities, this transition proved devastating for the city, as is evident from the SMDI (Scottish Government 2012). The figure below outlines the 'big four’ peripheral housing estates (see Figure 5 below);

Figure 5: Glasgow deprivation according to the SMDI 2012

The process of deindustrialization has been particularly felt in Scotland, and more specifically, the countries industrial heartland of Glasgow (Deuchar 2009). The population suffered significantly from globalised processes as a decline in employment corresponded with a rise in welfare dependency (Rodger 2008). Glasgow’s one time thriving ship building industry, along with other types of heavy industry, had been greatly reduced (Johnston and McIvor 2004). Like Wacqaunt's (2008) description of the US rustbelt, Scotland's West Coast had similarly fallen victim to larger global processes. Many communities which had previously flourished, now exacerbated towards a dilapidated state. Many of the newly 
developed peripheral housing estates had failed dramatically, falling into a dilapidated state and typically plagued by YSGs. Youth who were already poor, became further marginalised. Consequently, being a working-class city built around heavy industry, many of Glasgow’s concepts of masculinity had been tied to the workplace. Heavy lifting, construction, and hard work were all aspects of employment in which Glasgow's population had been able to display masculine traits of toughness, resilience, and strength (Johnston and McIvor 2004; Lawson 2013). Yet following deindustrialization, this masculine outlet has no longer proved possible. Similarly, where work was available, it often came in the form of the service sector, which was out of the question for a Glasgow male workforce who deemed it to be feminine (Kafalas 2003). Consequently, masculine pursuits became confined to the sphere of leisure for marginalized male youths.

Masculinity now located in the sphere of leisure resulted in YSGs seeking leisure facilitations in which they could express their masculinity. For poor marginalized youths the streets offered this pursuit. YSGs tended to express masculinity through YSG violence whereby confrontation was activity sought with other YSGs from neighbouring schemes (Fraser 2013; Patrick 1973). Fights could be the result of scheme raids, hanging around meeting points, or capitalising on technology via mobile phones, pirate radio stations, or even social media (Mclean Forthcoming). Social media in particular allows the YSG to access new technology and project images of itself (See Figure 6). The gang can label themselves, identify members and also label rival gangs with slogans such as 'F.T.Glen'. ${ }^{6}$ YSGs were in many ways cyber gangs, which existed only as a solid unit on the net (Sela-Shayovitz 2012). Whereas in realty membership was often fluid and loose associations would drift in and out of gang affiliation

\footnotetext{
${ }^{6} \mathrm{~F}$.T is a prefix used in conjunction with rival gang names. F.T stands for 'Fuck the'.
} 
which typically centred on the core. The gang in effect becomes a cyber gang, accessing social media to present pictures of itself as a cohesive unit when in fact this may not be the case.

Figure 6: YSGs on gang webpages. From top to bottom. Young Briggy (Brigdeton). Young Garren (Erskine). Young Boig (Springboig).

In addition, the rise of night time economy also enabled youths to use cheap leisure facilities to participate in YSG violence (Deuchar 2009). While there were a number of nightclubs available for over $18 s,{ }^{7}$ members of this age bracket were typically leaving YSGs, thus YSG activity was generally located to the under 18s or unders as it was referred to locally. Underage nightclubs were for youths under the age of 18. One unders in Glasgow which epitomised YSG violence above all others was Archoas nightclub. Archoas would be used as a social space for demonstrating YSG strength, and projecting the gang name city wide. YSGs would regularly meet in Archoas Roundroom, ${ }^{8}$ to engage in YSG confrontation and violence.

Recent years have seen a decline in YSG formation (Scottish Government 2015b). Following an amalgamation of the Scottish Police Service, it is arguable police have been able to more effectively allocate resources, funding, and spending to areas where it is most needed.

\footnotetext{
${ }^{7}$ In Glasgow nightclubs are typically either for under 18s or over 18s. This is in reference to years of age. ${ }^{8}$ The Roundroom was the unofficial name for the room and made reference to the dance floor being laid out in a circular fashion. The YSG with the greatest strength would hold the middle of the dance floor and contend with would be rivals. Typically, this took place in an aggressive undertone of pushing and barging while music played, but fights would regularly break out should either one of the gangs vying for middle position budge.
} 
Similarly, a number of Scottish Government funded initiatives, voluntary projects, and multiagency partnerships such as Family Action in Rodgerfield and Easterhouse (FARE), Community Initiative to Reduce Violence (CIRV) and No Knife Better Lives (NKBL) may well have equally contributed to the decline in YSG activity. However, upon closer inspection we see this decline has coincided with: a) a rise in SOCGs; and b) a move towards an era of advanced capitalism and consumer society. Thus a more detailed analysis is required.

\section{DISCUSSION}

Over the past century or more gang culture has steadily become firmly embedded into the very social fabric of Glasgow. Since industrialization gang formation has primarily presented itself in two main forms. Throughout industrialization the gang materialised in the form of razor gangs, while during and immediately post-deindustrialization YSGs came to the fore. However, while the latter is very much an antecedent of the former, both differ in their own unique ways. This can be attributed to the changing urban landscape and wider economic climate either found itself situated in. Throughout industrialization, Glasgow's heavy industry was booming. This led to a massive population influx of indigenous Scottish Protestants from the surrounding regions. Yet Catholic Irish also took advantage of these burgeoning employment opportunities, but in the form of seasonal work. However, once the great famine resulted in crop failures in Ireland, many were forced to make the move to Scotland a permanent one (Handley 1947). Setting up largely homogeneous communities, adjacent to existing Protestant communities resulted in considerable religious tension. Gang conflict would emerge (Davies 1998, 2013). The YSGs on the other hand were very much the result 
of social and economic restructuring following the Second World War. This resulted in: a) the creation of new, yet poorly built, extensive peripheral housing estates lacking the facilities necessary to sustain such large populations; and b) the deindustrialization of the city’s heavy industry which meant a primary working-class population epitomising tough masculinities (Lawson 2013), had neither opportunity to display them in the sphere of labour, nor the will to express them in the growing service sector. Marginalised youths locked in territorial confinement and devoid of legitimate masculine outlets would release such masculinities through the YSG.

While the wider urban landscape impacted directly upon gang formation and how gangs expressed themselves differently, this can largely be attributed to those individuals of whom the gang would comprise. For razor gangs territorial conflict was the veneer of sectarianism conflict. Coupled with the economic depression, massive unemployment would result, which saw the second-class Irish population further victimized as a source of cheap labour. With no work many gang members retained gang membership for a longer duration, well into adulthood (Davies 1998). As such, members had both the mental and physical maturity to engage in organised crime, or at least crime which is organised, successfully (Densley 2012; Hagedorn 1994, 1998). Similarly, prior to significant technology advances, improved transport links (such as the motorway), and more complex processes apropos globalization, crime was primarily locally situated (McLean 2017). Thus as crime could be carried out in the local environment it was not uncommon for razor gangs to partake in racketeering, heists, and armed robbery (Davies 1998). Razor gangs therefore had access to both the capabilities and opportunities to engage in gang organisation as a means for gang business. However, following the Second World War, employment was once again available to most, thus adults tended to work as opposed to making money through gang activity. This process was 
likewise aided by technological advancements in security, advances in automobiles, improved transportation, the creation of the house telephone, and the development of a more effective police force (Donnelly and Scott 2009). In addition, globalization meant that organised criminal opportunity steadily removed itself from the local environment and moved towards the global sphere; particularly as money became digitized (Sela-Shayovitz 2012). However, while razor gangs diminished, the tradition of having a youth branch persisted and became Young Teams (Bradshaw 2005).

For these Young Teams or YSGs, in addition to being developmentally too young, the technological advances, etc. outlined above, also contributed to there being little opportunity or possibility to engage in OC. However, a trait of the razor gang which YSGs could access was that of territorial conflict. But, with the reorganisation of Glasgow social housing, territorial violence would no longer revolve around sectarian division, but would rather be based purely upon post-code rivalry. Likewise, coinciding complex processes apropos of globalization, such as the rise in free market polices, Glasgow would undergo rapid deindustrialization. This meant that for young males from traditionally working-class backgrounds, the opportunity to express masculinity through work was no longer on offer, thus masculine expression was limited to the sphere of leisure, i.e. YSG violence. Evidently the YSG is an antecedent of the razor gangs, but it is likewise very much an extending branch of the same trunk. While both gangs are the result of a deeply embedded gang culture, intertwined with aspects of tough masculinities, gang formation on the other hand materializes in direct relation to the wider urban environment of that period. By examining this process, we are able to account for both a continued gang culture, while also accounting for gang differences. The wider social structure inevitably impacts upon those agents, and agencies, involved. 
Bauman (2005), Beck (1992), and Giddens (1992) are just some of the few prominent sociologists who argue that the western world is undergoing a paradigm shift, whereby society’s organisation is now firmly situated within the discourse of advanced capitalism, revolving around issues of risk and consumer identity. Consequently, this shift in social organisation has resulted in the 'disembedding' of communities (Giddens 1992), a rise in neoliberal ideology, increased emphasis on individualism, the development of not only the physical-self but also the digital-self, and a need to consume. Likewise, in a consumer society demanding our very participation, yet simultaneously neglecting to provide those adequate and legitimate, sources to do so, individuals are being forced balance risk with consumption power (Bauman 2005; Beck 2001). In advanced capitalist society, lives have come to revolve around the continual need for goods and thus finances (Roger 2008). So what does this need to balance risk and consumption look like for marginalised youth in Glasgow gangs?

In consumer society, social standing amongst marginalised males in isolated communities is no longer defined primarily through tough masculinities. Thus the YSG is now in decline. Yet coinciding with this process has been the increase of OC and SOCGs. Consequently, the Glasgow conurbation now retains more SOCGs than YSGs (Scottish Government 2015a; VRU 2011). Thus given that YSGs are territorially defined, it would stand to assume that some of these territories now retain several SOCGs as opposed to one YSG. It would therefore seem that territory no longer retains the same capability to define masculinity, rather the need to consume has become overpowering. SOCGs have been identified as primarily involved in drug supply, thus in the advanced capitalist society, where legitimate sources to engage in consumption have been removed, illegitimate sources have replaced 
them (Anderson 1999; Wacquant 2009). Globalised processes have aided the increased access to illegal drugs, and gangs have continually proved to be the key outlet for such commodities. While these insights have traditionally been applied to the US arena, both Densley (2012) and Pitts (2008) point out that such processes have now been extrapolated to the English context. Likewise, drawing upon Mclean (2017) we see that YSGs and SOCGs already retain numerous commonalities, therefore drawing upon McLean’s evolving gang model we can see that such features which refine gang organisation in efforts to engage in gang business, are gradually built upon, developed, and improved as the YSG begins its transition towards becoming a SOCG. Yet while this model provides insights into gang organisation, it is by no means one which is generalised to every YSG, but only those which retain certain intrinsically criminal features.

Given that YSGs have only been in decline in recent years, it would be difficult to assume or justify that all YSGs have become SOCGs. Rather, what we need to assess is whether or not the broader urban landscape still retains those features which deem YSG formations as necessary or desirable formations. Looking at Mclean’s evolving gang model we can see that YSG relationships are social in purpose and recreational in their activities, however in a society characterised by technological advancement in social media, social relationships themselves have become largely digital, this leaves little room for groups to gather in large crowds on street corners and as such the need to display masculinity or social standing in first of viewing grouped peers, via delinquency and/or violence, is also rendered as no longer necessary. Given that these groups never materialise; they never have a chance to engage in delinquent behaviour. When such groups do materialise, often such gatherings have been arranged in advance via social media or mobile phones, and thus a group agenda has often been set prior to formation. Thrasher (1927) importantly points out that street gangs are 
spontaneous groupings and delinquency is often an unplanned activity. Matza (1964) likewise suggests that delinquency in such groupings to be largely the result of both drifting and social boredom. Likewise, this also results in a decline in territoriality amongst youths, given that they never interact to the same degree with the local environment as those in previous decades. By looking at the SOCG we can see that relationships are based on business, and activities are for financial profit. In consumer society, relationships are in many ways business based, and activities are very much centred upon individual gain and consumption (often in the form of financial profit). Therefore, it is logical to assume that the rise in social media has allowed youths to begin to leapfrog the YSG stage as it no longer retains the same creditability as in prior years and instead begin to form YCGs and SOCGs. This would account for the continuation of an embedded gang culture, a decline in street violence and YSGs, and also a rise in OC.

However, as with all theoretical conceptualizations, they are merely that, theoretical conceptualizations. And while many of the insights for this theory have been derived from primary qualitative data from prior research with YSG members and SOCG members $(n=35)$, and practitioners $(\mathrm{n}=5)$, regarding the possibilities for gang organisations as a means for gang business, such sampling is too small and also possibly skewed ${ }^{9}$. Rather a greater depth of empirical research, particularly out with the Glasgow conurbation, would be required to make broad generalizations and investigate the effects of social media and technological advancements on wider trends in youth offending. Perhaps though, more importantly yet equally socially detrimental, only time will tell whether or not SOCG, and the like, are the new evolving face of Glasgow gangs which are far from gone, only evolved.

\footnotetext{
${ }^{9}$ See Mclean (2017) and Mclean (Forthcoming) for detail.
} 


\section{REFERENCES}

Alonso, Alejandro A. 2004. "Racialized Identities and the Formation of Black Gangs in Los Angeles”. Urban Geography 25(7):658-674.

Anderson, Elijah. 1999. Code of the Street. New York: W. W. Norton.

Bartie, Angela. 2010. "Moral Panics and Glasgow Gangs: Exploring the New Wave into Glasgow Hooliganism, 1965-1970.” Contemporary British History 24(3):385- 408.

BBC News. 2013. Glasgow ranked UK's most violent area. 24th April.

Beck, Ulrich. 1992. Risk Society: Towards a New Modernity. London: Sage Publications Ltd.

Boyle, James. 1977. A Sense of Freedom. London: Pan Books.

Davies, Andrew. 1998. “Street Gangs, Crime and Policing in Glasgow during the 1930s: The Case of the Beehive Boys.” Social History 23(3): 3-4.

Davies, Andrew. 2007. “The Scottish Chicago? From Hooligans to Glasgow in the Late 1920’s.” Cultural and Social History 4(4):511-527. 
Davies, Andrew. 2013. City of Gangs: Glasgow and the Rise of the British Gangster. London: Hodder and Stoughton.

Densley, James A. 2013. How Gangs Work: An Ethnography of Youth Violence. London: Palgrave Macmillan.

Deuchar, Ross. 2009. Gangs, Marginalised Youth and Social Capital. Stoke-on-Trent: Trentham Books.

Deuchar, Ross. 2013. Policing Youth Violence: Transatlantic Connections. London: Trentham Books/IOE Press.

Farrington David P., Jeremy W. Coid, and Joseph Murray. 2009. "Family Factors in the Intergenerational Transmission of Offending.” Criminal Behaviour and Mental Health 19(2): 109-124.

Fraser, Allister. 2013. "Street Habitus: Gangs, Territorialism and Social Change in Glasgow.” Journal of Youth Studies 16(8):970-985. 
Fraser, William H. 2011. Providence and empire. religion, politics and society in the United Kingdom 1815-1914. Scottish Historical Review. 90, (229): 158-159

Giddens, Anthony. 1992. The Transformation of Intimacy. Cambridge: Polity Press.

Handley, James E. 1947. The Irish in Modern Scotland. Cork: Cork University Press.

Hagedorn, John M. 1994. Homeboys, Dope Fiends, Legits, and New Jacks. Criminology 32(2): 197-219.

Hagedorn, John M. 1998. People and Folks: Gangs, Crime and the Underclass in a Rustbelt City. Chicago: Lakeview Press.

Johnston, Ronnie and Arthur McIvor. 2004. Dangerous Work, Hard Men and Broken Bodies: Masculinity in the Clydeside Heavy Industries, c. 1930-1970s. Labour History Review 69(2):135-151.

Kafalas, Marie. 2003. Working-Class Heroes: Protecting Home, Community, and Nation in a Chicago Neighbourhood. University of California Press. Los Angeles. 
Kenefick, William. 2000. Rebellious and Contrary: The Glasgow Dockers, 1853-1932. Tuckwell Publishers. Edinburgh.

Klein, Malcolm W., Hans-Jürgen Kerner, Cheryl L. Maxson, and Elmar G. M. Weitekamp. 2001. The Eurogang Paradox: Street Gangs and Youth Groups in the U.S. and Europe. California: Springer Publishing.

Lawson, Robert. 2013. 'The Construction of “Tough” Masculinity: Negotiation, Alignment and Rejection.' Gender and Language 7(3):369-95.

McLean, Robert (2017). An Evolving Gang Model in Contemporary Scotland. Journal of Deviant Behaviour. DOI: 10.1080/01639625.2016.1272969

Mclean, Robert (Forthcoming). Discovering Young Crime Gangs in Glasgow: Street gang Organisation as a Means for Gang Business. Unpublished Thesis. University West of Scotland.

Matza, David. 1964. Delinquency and Drift. New Jersey: Prentice-Hall.

Patrick, James. 1973. A Glasgow Gang Observed. London: Redwood Press. 
Pitts, John. 2008. Reluctant Gangsters: The Changing Face of Youth Crime. Devon: Willan Publishing.

Roger, John J. 2008. Criminalising Social Policy: Anti-Social Behaviour and Welfare in a De Civilized Society. Devon: Willian Publishing

Scottish Government. 2012. Scottish Index of Multiple Deprivation. Edinburgh: Scottish Government.

Scottish Government. 2015a. Scotland Serious Organised Crime Strategy Report. Edinburgh: Scottish Government

Scottish Government. 2015b. Knife Crime in Glasgow Continues to Fall. Scottish Government. Edinburgh.

Sillitoe, Percy Sir. 1956. Cloak without Dagger. London: Pan.

Smith, Roger. 1975. The Politics of an Overspill Policy: Glasgow, Cumbernauld and the Housing and Town Development (Scotland) Act. Unpublished Thesis. University of Glasgow. 
Sela-Shayovitz, Revital. 2012. Gangs and the Web: Gang Members’ Online Behavior. Journal of Contemporary Criminal Justice 28(4):389-405.

Thrasher, F. 1927. The Gang. Chicago, IL: University of Chicago Press

Violence Reduction Unit. 2011. The Violence Must Stop: Glasgow’s Community Initiative to Reduce Violence. Second year report. Glasgow: VRU.

Wacquant, Loic. 2008. Urban Outcast: A Comparative Sociology of Advanced Marginality. Polity Press: Cambridge

Wacquant, Loic. 2009. Punishing the Poor: The Neoliberal Government of Social Insecurity. London: Duke University Press. 